\title{
TOTAL ANTIOXIDANT CAPACITY (TAC) VALUES AND THEIR CORRELATION WITH INDIVIDUAL ANTIOXIDANTS IN SERUM OF HEALTHY BEAGLES
}

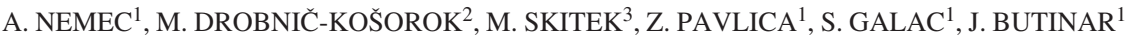

${ }^{1}$ Clinic for Small Animal Medicine and Surgery, Veterinary Faculty in Ljubljana, Slovenia ${ }^{2}$ Institute of Physiology, Pharmacology and Toxicology, Veterinary Faculty in Ljubljana, Slovenia ${ }^{3}$ Clinical Institute of Clinical Chemistry and Biochemistry, Medical Centre Ljubljana Slovenia

Received May 16, 2000

Accepted November 22, 2000

\begin{abstract}
Nemec A., M. Drobnič-Košorok, M. Skitek, Z. Pavlica, S. Galac, J. Butinar: Total Antioxidant Capacity (TAC) Values and Their Correlation with Individual Antioxidants in Serum of Healthy Beagles. Acta Vet. Brno, 2000, 69: 297-303.

The paper aims to establish a range for serum Total Antioxidant Capacity (TAC) and to determine the correlation between TAC and some individual antioxidants (vitamin A and E, lipid standardised vitamin $\mathrm{E}$ [Vit E/LS/], $\beta$-carotene, total bilirubin and albumin) in a uniform population of beagle dogs. Emphasis was directed on their general health status to establish a basis for future investigation of the role of TAC in diseases of dogs as species most frequently studied in veterinary medicine. The animal body possesses a variety of protective antioxidant substances that act as a harmoniously and finely tuned mechanism to neutralise harmful oxidants. TAC measurements provide a tool for establishing links between antioxidant capacity and the risk of disease as well as for monitoring of antioxidant therapy. Serum samples of 19 healthy beagles were assayed for TAC on LP 700 photometer (Dr. Lange, Germany) with a commercially available TAS kit ("Total Antioxidant Status" - TAS; Randox, Crumlin, UK). TAS kit measures the capacity of all of the antioxidants present in serum or plasma sample. The assay is based on the suppression of the absorbance of the radical cation of 2,2"-azinobis (3-ethylbenzothiazoline-6-sulfonate) (ABTS ${ }^{\bullet+}$ ) by antioxidants. Assay results are expressed as mmol/l of Trolox (6-hydroxy-2, 5, 7, tetramethylchroman-2-carboxylic acid - a water-soluble analogue of $\alpha$-tocopherol) equivalents. The range for TAC expressed as mean \pm SD resulted in $1.08 \pm 0.08 \mathrm{mmol} / 1$. TAC correlated positively with albumin $(r=0.18)$, vitamin $E(r=0.14)$ and Vit $E(L S)(r=0.20)$, and negatively with total bilirubin $(\mathrm{r}=-0.30)$, vitamin $\mathrm{A}(\mathrm{r}=-0.15)$ and $\beta$-carotene $(\mathrm{r}=-0.13)$ although no significant correaltion has been found.

Antioxidant capacity, antioxidants, free radicals, dog
\end{abstract}

A wide range of substances, known as Reactive Oxygen Species (ROS), consisting of free radicals such as $\mathrm{O}^{2 \bullet}, \mathrm{OH}^{\bullet}$, and other non-radical oxygen derivatives such as hydrogen peroxide $\left(\mathrm{H}_{2} \mathrm{O}_{2}\right)$, hypochlorous acid $(\mathrm{HOCl})$ and singlet Oxygen $\left({ }^{1} \mathrm{O}_{2}\right)$ are constantly generated in vivo as an integral part of metabolism, as part of a controlled inflammatory reaction and by exposure to environmental factors. A free radical can be defined as any species capable of independent existence that contains one or more unpaired electrons (Halliwell 1996). Non-radical oxygen derivatives are substances capable of radical formation in intra- and extra-cellular environments ( $\mathrm{Cao}$ and Prior 1998; Chapple 1997; Halliwell 1997). The pathological increase of ROS generation has already been recognised in over one hundred human and animal diseases including cancer, cardiovascular disease, diabetes mellitus, male infertility, renal disease and dialysis, cataracts, neurological, liver, periodontal, lung and inflammatory diseases (Halliwell 1996; Lantos et al. 1997; Moore et al. 1994; Pinzani et al. 1998). ROS circulate freely in the body with access to all organs and tissues. They cause tissue damage by a variety of different mechanisms, which

Address for correspondence:

Alenka Nemec

Clinic for Small Animal Medicine and Surgery

Phone: + 386014779301

E-mail: nemecal@mail.vf uni-lisi

Gerbičeva 60, 1115 Ljubljana, Slovenia

http://www vfu $z$ /acta-vet/actavetht 
include DNA damage, lipid peroxidation (through activation of cyclooxygenases and lipooxygenases), protein damage, oxidation of important enzymes, e. g. anti-proteases such as $\alpha 1$-antitrypsin, and stimulation of pro-inflammatory cytokine release by monocytes and macrophages (Chapple 1997). It is therefore not surprising that all oxygen consuming organisms have developed complex antioxidant systems to counteract ROS and to reduce their damage (Cao et al. 1995; Halliwell 1996). Antioxidants may be regarded as those substances which, present at low concentrations, compared to those of an oxidisable substrate, will significantly delay or inhibit oxidation of that substrate (Halliwell 1995). There are different classifications of antioxidants. According to their mode of action Chapple (1997) differentiates them into three main groups:

- "Preventative antioxidants" which prevent the formation of new ROS, e. g. caeruloplasmin, metallothioniene, albumin, myoglobin, ferritin, transferrin.

- "Scavenging antioxidants" remove ROS once formed, thus preventing radical chain reactions. These include reduced glutathione $(\mathrm{GSH})$, vitamine $\mathrm{E}$ ( $\alpha$-tocopherol), vitamin $\mathrm{C}$ (ascorbic acid), $\beta$-carotene, uric acid and bilirubin.

- "Enzyme antioxidants" that function by catalysing the oxidation of other molecules. This group includes superoxide dismutase, glutathione reductase, glutathione peroxidase, catalase and metalloenzymes.

The serum contains many different antioxidants that may be important for general health maintenance. These include ascorbic acid, $\alpha$-tocopherol, $\beta$-carotene, uric acid, bilirubin, and albumin. In addition, trace amounts of antioxidant enzymes such as glutathione peroxidase and superoxide dismutase are found in serum to a lesser extent ( $\mathrm{Ca}$ o et al. 1993; Chapple 1997; Chapple et al. 1997). In diabetes, markers of oxidative stress have been shown to be elevated whereas vitamin $\mathrm{C}$ levels are reduced. Some studies have shown that treatment with antioxidants, particularly vitamin $\mathrm{C}$, can reduce both oxidative stress and protein glycation and may help to reduce the risk of developing diabetic complications (Erikas s on et al. 1995; Young et al. 1995). Recently Barros et al. (1999) reported low plasma vitamin $C$ levels in cataractous dogs compared with healthy dogs. Decreased plasma levels of vitamin $\mathrm{C}$ may indicate a decrease in the antioxidant capacity of aqueous humour. Heliovarra et al. (1994) found low levels of vitamin E, $\beta$-carotene and selenium to be associated with increased risk of rheumatoid arthritis. The number of different antioxidant components in serum and tissues makes it relatively difficult to measure each antioxidant component separately. In addition, since there is a co-operation between various antioxidants, looking at one in isolation from rest may not accurately reflect their combined action. Therefore, the measurement of the total serum antioxidant capacity seems to represent a suitable biochemical parameter for evaluating the overall antioxidant status resulting from antioxidant intake or production and their consumption by the increasing levels of oxidative stress (Cao et al. 1993; Cao and Prior 1998; Chapple 1997; Pinzani et al. 1998; Whitehead et al. 1992). Several methods have been developed to evaluate the total antioxidant capacity of serum of plasma (Cao et al. 1993; Cao et al. 1995; Miler at al. 1993; Rice-Evans and Miler 1994; Whitehead et al. 1992). These methods are all essentially inhibition methods. A free radical species is generated, there is an end point by which the presence of the radical is detected, and the antioxidant activity of the added sample inhibits the end point by scavenging the free radical. Methods vary greatly as to the radical that is generated, reproducibility of the generation process, and the end point that is used (Rice-Evans and Miller 1994).

The aim of our study was to establish the range for serum Total Antioxidant Capacity (TAC) and to determine the correlation between TAC and some individual antioxidants (vitamin A and E, lipid standardised vitamin E [Vit E(LS)], $\beta$-carotene, total bilirubin and albumin) in healthy beagles. 


\section{Materials and Methods}

Animals

19 beagles, 15 females and 4 males, ranging from 1 to 3 years, were considered healthy on the basis of history, results of physical examination, haematological parameters, i.e. complete blood count $(\mathrm{CBC})$, white cell differential count (WCDC) and serum biochemical profile.

Samples

Venous blood samples were collected from fasted dogs into plain and EDTA - containing tubes. Samples in plain tubes stood for $30 \mathrm{~min}$ at $4{ }^{\circ} \mathrm{C}$ to clot, prior to centrifugation ( $3000 \mathrm{rpm}$ for $10 \mathrm{~min}$ ) and separation of serum. Serum samples were stored at $-70^{\circ} \mathrm{C}$ and assayed within 2 weeks in duplicate for TAC and various biochemical parameters indices (urea, creatinine, sodium, potassium, total bilirubin, total protein, albumin, alanin-aminotransferase [ALT], cholesterol, triglycerides, $\beta$-carotene and vitamins A and E). EDTA blood samples for CBC and WCDC determination were stored at room temperature and analysed from 1 to $5 \mathrm{~h}$ after sampling.

TAC measurements

Serum samples of 19 healthy beagle dogs were assayed for TAC on LP 700 photometer (Dr. Lange, Germany) with a commercially available TAS kit ("Total Antioxidant Status" - TAS; Randox, Crumlin, UK), following the instructions of the kit. The assay is based on the reduction of free radicals (ABTS ${ }^{+}-2,2^{2}$-azinobis (3ehylbenzothiazoline-6-sulfonate) measured as a decrease of absorbance at $600 \mathrm{~nm}$ at $3 \mathrm{~min}$ by antioxidants. The $\mathrm{ABTS}^{*+}$ radical cation is formed by the interaction of ABTS with ferrylmyoglobin radical species, generated by the activation of metmyoglobin with hydrogen peroxide. The suppression of the absorbance of the $\mathrm{ABTS}^{-+}$radical cation by serum antioxidants was compared with that from a Trolox (6-hydroxy-2, 5, 7, -tetramethylchroman-2carboxylic acid) which is included as part of the TAS kit. The results are expressed as mmol/l of Trolox equivalents In addition, control serum (Randox, Crumlin, UK) with TAC value of 1.0 to $1.36 \mathrm{mmol} / \mathrm{l}$ was assayed in each batch of samples for the estimation of analytical imprecision (between-batch coefficient of variation).

Determination of haematological parameters

CBC and WCDC were determined by an automated laser haematology analyser Bayer-Technicon $\mathrm{H}^{*} 1$ (Bayer - Technicon, Tarrytown, New York) with species specific software ( $\mathrm{H}^{*} 1$ Multi-Species V30 Software, Tarrytown, New York). CBC includes white blood cells (WBC), red blood cells (RBC), haemoglobin concentration (HGB), haematocrit (HCT), mean corpuscular volume (MCV), mean corpuscular haemoglobin (MCH), mean corpuscular haemoglobin concentration (MCHC) and platelets (PLT). WCDC represent a six-part differential neutrophils (NEUT), lymphocytes (LYMPH), monocytes (MONO), eosinophils (EOS), basophils (BASO) and large unstained cells (LUC), both as a percentage (data not shown) and absolute count. The LUC category consists of a heterogeneous population of all large cells that fail to exhibit any peroxidase activity (atypical lymphocytes, immature granulocytes and blasts).

Determination of biochemical parameters

Urea, creatinine, sodium $(\mathrm{Na})$, potassium $(\mathrm{K})$, total bilirubin, total protein, albumin, uric acid and alaninaminotransferase (ALT) were determined by automated chemistry analyser Ektachem 250 (Kodak, Rochester, New York). Cholesterol and triglycerides were determined by Abbott reagents using automated chemistry analyser ALCYON $^{\mathrm{TM}} 300$ (Abbott, Illinois, USA). Serum $\beta$-carotene concentrations were determined by spectrophotometric method at $450 \mathrm{~nm}$. The preparation of the serum included saponification of the $\beta$-carotene with alcohol solution of potassium hydroxide $(\mathrm{KOH})$ and extraction with n-heptane. Serum vitamin A and E concentrations were determined by fluorometric methods. The preparation of the serum included saponification of the vitamins $\mathrm{A}$ and $\mathrm{E}$ with alcohol solution of potassium hydroxide $(\mathrm{KOH})$ and extraction with petrolether. Lipid standardised vitamin $\mathrm{E}$ (Vit E[LS]) values were calculated as the ratios of vitamin $\mathrm{E}$ to the sum of cholesterol and triglycerides. They are expressed as $\mu \mathrm{mol}$ vitamin $\mathrm{E} / \mathrm{mmol}$ total cholesterol plus triglycerides (Benzie et al. 1998; Jost et al. 1999).

Statistical evaluation

Statistical analyses were done using Statistica for Windows (STATSOFT Incorporation, 1993). Means and standard deviations were calculated for all haematological and biochemical parameters. Correlation coefficients (r) were calculated for TAC and some individual antioxidants. Correlations were considered significant at the level $P<0.05$.

\section{Results}

The serum TAC values obtained for 19 beagle dogs varied between 0.93 and $1.27 \mathrm{mmol} / \mathrm{l}$, with a mean value $1.08 \pm 0.08 \mathrm{mmol} / \mathrm{l}$, median value $1.10 \mathrm{mmol} / \mathrm{l}$ and valued for lower quartile $1.02 \mathrm{mmol} / \mathrm{l}$ and upper quartile $1.12 \mathrm{mmol} / \mathrm{l}$. The analytical imprecision was 
estimated by determination of between-batch coefficient of variation calculated on the basis of 20 analyses of control serum. The results are summarised in Table 1.

Table 1

Between-batch precision of TAC assay

\begin{tabular}{|l|l|}
\hline Parameter & Control serum \\
\hline Number & 20 \\
\hline Mean $(\mathrm{mmol} / \mathrm{l})$ & 1.17 \\
\hline SD & 0.03 \\
\hline CV $(\%)$ & 2.8 \\
\hline
\end{tabular}

Haematological and biochemical values of beagle dogs are presented in Tables 2, 3 and 4. Biochemical and haematological values were consistent with other published normal values (Bush 1998; Tvedten 1999; Baker et al. 1986). There are no data available for Vit (E (LS) in dogs in literature. The uric acid values were less than $12 \mu \mathrm{mol} / \mathrm{l}$ in all $19 \mathrm{beagle}$ dogs.

Table 2

$\mathrm{CBC}$ values expressed as mean $\pm \mathrm{SD}$

\begin{tabular}{|c|c|c|c|c|c|c|}
\hline WBC & RBC & HGB & HCT & MCV & MCHC & PLT \\
\hline$\left(10^{9} / 1\right)$ & $\left(10^{12} / 1\right)$ & $(\mathrm{g} / \mathrm{l})$ & $(1 / 1)$ & $(\mathrm{fl})$ & $(\mathrm{g} / \mathrm{l})$ & $\left(10^{9} / 1\right)$ \\
\hline $9.84 \pm 2.53$ & $7.43 \pm 0.46$ & $173 \pm 9$ & $0.54 \pm 0.028$ & $72.5 \pm 1.6$ & $321 \pm 5$ & $357 \pm 61$ \\
\hline
\end{tabular}

No significant correlation $(P>0.05)$ was found between TAC and individual antioxidants such as albumin, total bilirubin, vitamin A, $\beta$-carotene, vitamin $\mathrm{E}$ and Vit $\mathrm{E}(\mathrm{LS})$.

Table 3

WCDC values expressed as mean \pm SD

\begin{tabular}{|c|c|c|c|c|c|}
\hline NEUT & LYMPH & MONO & EOS & BASO & LUC \\
\hline$\left(10^{9} / \mathrm{L}\right)$ & $\left(10^{9} / \mathrm{L}\right)$ & $\left(10^{9} / \mathrm{L}\right)$ & $\left(10^{9} / \mathrm{L}\right)$ & $\left(10^{9} / \mathrm{L}\right)$ & $\left(10^{9} / \mathrm{L}\right)$ \\
\hline $5.95 \pm 1.74$ & $3.20 \pm 1.01$ & $0.30 \pm 0.13$ & $0.29 \pm 0.17$ & $0.024 \pm 0.0016$ & $0.056 \pm 0.035$ \\
\hline
\end{tabular}

Table 4

Biochemical values expressed as mean \pm SD

\begin{tabular}{|l|c|l|c|}
\hline Parameter & Value & Parameter & Value \\
\hline Urea $(\mathrm{mmol} / \mathrm{l})$ & $3.0 \pm 1.0$ & Albumin $(\mathrm{g} / \mathrm{l})$ & $33.9 \pm 3.2$ \\
\hline Potassium $(\mathrm{mmol} / \mathrm{l})$ & $4.1 \pm 0.2$ & Cholesterol $(\mathrm{mmol} / \mathrm{l})$ & $4.8 \pm 0.88$ \\
\hline Sodium $(\mathrm{mmol} / \mathrm{l})$ & $150 \pm 3$ & Triglycerides $(\mathrm{mmol} / \mathrm{l})$ & $0.3 \pm 0.08$ \\
\hline Creatinine $(\mu \mathrm{mmol} / \mathrm{l})$ & $57.1 \pm 10.8$ & Vitamin A $(\mu \mathrm{mol} / \mathrm{l})$ & $11.2 \pm 4.2$ \\
\hline ALT $(\mu \mathrm{kat} / \mathrm{l})$ & $0.66 \pm 0.33$ & ß-carotene $(\mu \mathrm{mol} / \mathrm{l})$ & $0.2 \pm 0.1$ \\
\hline Total bilirubin $(\mu \mathrm{mol} / \mathrm{l})$ & $7.0 \pm 0.09$ & Vitamin E $(\mu \mathrm{mol} / \mathrm{l})$ & $54.0 \pm 15.8$ \\
\hline Total protein $(\mathrm{g} / \mathrm{l})$ & $62.5 \pm 2.8$ & Vit E $(\mathrm{LS})$ & $10.5 \pm 3.2$ \\
\hline
\end{tabular}

Correlation coefficients between TAC and some individual antioxidants and $P$ values are given in Table 5. 
Table 5

Least squares linear regression corrrelation of TAC values with some individual antioxidants

\begin{tabular}{|l|c|c|}
\hline Individual antioxidant & Correlation coefficient (r) with TAC & $P$ value \\
\hline Albumin & 0.18 & 0.46 \\
\hline Total bilirubin & -0.30 & 0.20 \\
\hline Vitamin A & -0.15 & 0.55 \\
\hline$\beta$-carotene & -0.13 & 0.59 \\
\hline Vitamin E & 0.14 & 0.58 \\
\hline Vit E(LS) & 0.20 & 0.43 \\
\hline
\end{tabular}

TAC negatively correlated with total bilirubin $(r=-0.30)$, vitamin $\mathrm{A}(\mathrm{r}=-0.15)$ and $\beta$-carotene $(\mathrm{r}=-0.13)$. There was a positive, but small corrrelation with albumin $(r=0.18)$, vitamin $\mathrm{E} r=0.14)$ and Vit $(\mathrm{LS})(\mathrm{r}=0.20)$

\section{Discussion}

Limited number of studies and experimental data about free radicals and serum total antioxidant capacity in dogs are available in spite of a great interest and progress in this area of medicine. Our study included a uniform population of beagle dogs with particular emphasis on their general health status to establish a basis for future investigation of role of TAC in diseases of dogs as the species most frequently studied in veterinary medicine. Based on a number of haematological and biochemical values that were all within physiological ranges, the population investigated was considered healthy. This might be an indirect proof for obtained TAC values to be regarded as normal for dogs. The serum TAC values were obtained by using TAS kit that enables rapid and reproducible measurement of total antioxidant capacity of serum or plasma. The range for TAC in investigated population, expressed as mean $\pm \mathrm{SD}$, was $1.08 \pm 0.08 \mathrm{mmol} / \mathrm{l}$ and in accordance with data obtained by Gaal and Kopal (1997) with the mean value of $1.10 \pm 0.45 \mathrm{mmol} / \mathrm{l}$, when the same method was used. There were no data available about the breed and general health status of the population investigated in this comparable study.

Several human studies investigated a correlation between TAC and different individual antioxidants, i. e. uric acid as major antioxidant in humans, albumin, vitamin $\mathrm{A}$ and $\mathrm{E}$ and bilirubin (Cao and Prior 1998; Chapple 1997; Dailly et al. 998; Lands et al. 2000; Moore et al. 1994). As no data could be obtained about the correlation between TAC and specific individual antioxidants in dogs, our study also focused on interrelation between TAC and albumin, total bilirubin, vitamin A and E, $\beta$-carotene and Vit E(LS). As abnormally high serum lipid concentrations can lead to false interpretation of serum vitamin E concentration we also correlated Vit E(LS) - lipid standardised vitamin E, calculated as the ratio of vitamin $E$ to the sum of cholesterol and triglycerides (Benzie et al. 1998; Jost et al. 1999).

Most of human studies showed a correlation of TAC and individual antioxidant parameters. Although statistically significant, the correlations obtained were relatively small and considered related to a complex, non-linear interaction between various components while studies on groups of human patients with particular disease i. e. cystic fibrosis show different pattern of interrelation like significant correlation with uric acis but not with albumin, vitamin A or E or lymphocyte glutathione concentration (Lands et al. 2000). In experimentally induced diabetes in rats TAC significantly correlated with plasma albumin levels (Feillet-Coudray et al. 1999) or direct, highly significant correlation of TAC and bilirubin was found in neonatal plasma (Gopinathan et al. 1994). As no studies 
of interrelation between TAC and individual antioxidants in dogs could be found in available literature we were not able to make comparisons with related studies although our data showed somehow different results compared to human studies. None of the correlations was significant whereas some correlated negatively, like total bilirubin $(r=-0.30)$, vitamin $A(r=$ $-0.15)$ and $\beta$-carotene $(r=-0.13)$ and others positively, like albumin $(r=0.18)$, viitamin $E(r=$ $0.14)$ and Vit $\mathrm{E}(\mathrm{LS})(\mathrm{r}=0.20)$. Compared to human studies there was no attempt to make correlation between TAC and uric acid due to its extremely low serum concentrations (reference range between 0 and $59 \mu \mathrm{mol} / \mathrm{l}$ ) and clinical insignificance except probably in Dalmatians. They are known to have a defect in uric acid metabolism due to a failure to convert uric acid to soluble salts along with impaired transport of urate across the hepatocyte membrane and in hyperuricaemic dogs with portosystemic vascular anomalies due to liver insufficiency (Center and Magne 1990).

Most investigators conclude that TAC appears to represent a mixed antioxidant response, rather than response to a single antioxidant. While being responsive to oxidative stress, the mechanisms of the response may differ between clinical situations, such that the clinical significance of changes in serum TAC remains to be defined. Further investigations should be oriented towards determination of TAC and its correlation with different individual antioxidants in a group of canine population with different, accurately defined pathological and clinical syndromes.

\section{Celkové hodnoty antioxidační kapacity séra (TAC) a korelace TAC $\mathrm{s}$ jednotlivými antioxidanty u zdravých psů plemene bígl}

Cílem studie bylo určit rozmezí celkové antioxidační kapacity (TAC) séra a stanovit korelace mezi TAC a některými individuálními antioxidanty (vitamin A a E, lipidový standardizovaný vitamin E (VitE(LS)), beta-karoten, celkový bilirubin a albumin) v uniformní populaci bíglů. Důraz byl kladen na celkový zdravotní stav zvířat jako podklad pro hodnocení úlohy TAC při onemocnění psů, nejčastěji sledovaného druhu zvířat ve veterinární medicíně.

Organismus má různé ochranné antioxidační substance, které působí jako harmonicky a jemně nastavený mechanismus neutralizující škodlivé oxidanty. Měření celkové antioxidační kapacity poskytuje podklad pro stanovení vztahu mezi antioxidační kapacitou a rizikem vzniku onemocnění a pro monitoring antioxidační terapie.

Celková antioxidační kapacita byla měřena v 19 vzorcích séra zdravých bíglů na fotometru LP 700 (Dr. Lange, Německo) s komerčním setem TAS („Total Antioxidant status“ - TAS; Randox, Crumlin, UK). Pomocí setu lze měřit kapacitu všech antioxidantů v séru nebo ve vzorcích plazmy. Metoda je založena na supresi absorbance radikálu, kationu 2,2 $2^{1}$ - azinobis(3-etylbenzotiazolinu-6-sulfonátu) (ABTS ${ }^{+}$) antioxidanty.

Výsledky metody jsou vyjádřeny $\mathrm{v}$ mmol/l troloxových (6-hydroxy-2,5,7,-tetrametylchromanu-2-kyseliny karboxylové - ve vodě rozpustného analogu alfa tokoferolu) ekvivalentech. Rozmezí TAC je vyjádřeno jako průměrná SD v 1,08 0,08mmol/1. TAC koreloval pozitivně s albuminem $(\mathrm{r}=-0,30)$, s vitaminem $\mathrm{A}(\mathrm{r}=-0,15)$ a s beta-karotenem $(\mathrm{r}=-0,13)$, ačkoliv významné korelace zjištěny nebyly.

\section{References}

BAKER, H., SCHOR, S. M., MURPHY, B. D., De ANGELIS, B., FEINGOLD, S., FRANK, O. 1986: Blood vitamin and choline concentrations in healthy domestic cats, dogs, and horse. Am. J. Vet. Res. 47: 1468-1471 BARROS, P. S. M., ANGELOTTI, A. C., NOBRE, F., MORALES, A., FANTONI, D. T., BARROS, S. B. M. 1999: Antioxidant profile of cataractous English Cocker Spaniels. Vet. Ophthalmology 2: 83-86

BENZIE, I. F., JANUS, E. D., STRAIN, J. J. 1998: Plasma ascorbate and vitamin E levels in Hong Kong Chinese. Eur. J. Clin. Nutr. 52(6): 447-451

BUSH, B. M. 1998: Interpretation of laboratory results for small animal clinicians. Blackwell Science Ltd, United Kingdom, pp. 478-483 
CAO, G. ALESSIO, H. M., CUTLER, R. G. 1993: Oxygen-radical absorbance capacity assay for antioxidants. Free Rad. Res. Med. 14: 303-311

CAO, G., VERDON, C. P., WU, A. H. B., WANG, H., PRIOR, R. L. 1995: Automated assay of oxygen radical absorbance capacity with the COBAS FARA II. Clin. Chem. 41: 1738-1744

CAO, G., PRIOR, R. L. 1998: Comparison of different analytical methods for assesing total antioxidant capacity of human serum. Clin. Chem. 44/6: 1309-1315

CENTER, S. A., MAGNE, M. L. 1990: Historial, Physical Examination, and Clinicopathologic Features of Portosystemic Vascular Anomalies in the Dog and Cat. Seminars in Veterinary Medicine and Surgery (Small Animals) 5(2): 83-93

CHAPPLE, I. L C. 1997: Reactive oxygen species and antioxidants in inflammatory diseases. J. Clin. Period. 24: 287-296

CHAPPLE, I. L. C., MASON, G. I., GARNER, I., MATTHEWS, J. B. THORPE, G. H., MAXWELL, S. R. J., WHITEHEAD, T. P. 1997: Enhanced chemiluminiscent assay for measuring the total antioxidant capacity of serum, saliva and cervicular fluid. Ann. Clin. Biochem. 34: 412-421

DAILLY, E., URIEN, S., BARRE, J., REINERT, P., TILLEMENT, T. P. 1998: Role of bilirubin in the regulation of the total peroxyl radical trapping antioxidant activity of plasma in sickle cell disease. Biochem. Biphys. Res. Commun. 248: 303-306

ERIKASSON, J., KOHVAKKA, A. 1995: Magnesium and ascorbic acid supplementation in diabetes mellitus. Ann. Nutr. Metab. 39: 217-223

FEILET-COUDRAY, C., ROCK, E., COUDRAY, C., GRZELKOWSKA, K., AZAIS-BREASCO, V., DARDEVET, D., MAZUR, A. 1999: Lipid peroxidation and antioxidant status in experimental diabetes. Clin. Chem. Acta 284: $31-43$

GAAL, T., KOPAL, D. 1997: Comparative studies on total antioxidant status )TAS) blood plasma of different animal species. In: Poster abstracts of $3^{\text {rd }}$ European Comparative Clinical Pathology (ECCP) Congress. Breda, The Netherlands, 22-25 April, p. 61

GOPINATHAN, V., MILLER, N. J., MILNER, A. D., RICE-EVANS, C. A. 1994: Bilirubin and ascorbate antioxidant activity in neonatal plasma. FEBS LETT. 349: 197-200

HELIOVARRA, M., KNEKT, P., AHO, K., AARAN, R. K. ALFTHAN, G., AROMAA, A. 1994: Serum antioxidants and risk of rheumatoid arthritis. Ann. Rheum. Dis. 53: 51-53

HALLIWELL, B. 1995: The definition and measurement of antioxidants in biological system. Free Rad. Biol. Med. 18: $125-126$

HALLIWELL, B. 1996: Antioxidants in human health and disease. Ann. Rev. Nutr. 16: 33-50

JOST, W. H., VORAN, A., TRABERT, W., KONIG, J., SCHIMRIGK, K. 1999: The oral vitamin E tolerance test - an attempt at standardisation. Wien Klin. Wochenschr. 111: 517-522

LANDS, L. C., GREY, V. L., GRENIER, C. 2000: Total plasma antioxidant capacity in cystic fibrosis. Pediatr. Pulmonol. 29: 81-87

LANTOS, J., ROTH, E., CZOPF, L., NEMES, J., GAL, I. 1997: Monitoring of plasma total antioxidant status in different diseases. Acta Chir. Hung. 36: 188-189

MILLER, J. N., RICE-EVANS, C., DAVIES, M. J. GOPINATHAN, V., MILNER, A. 1993: A novel method for measuring antioxidant capacity and its application to monitoring the antioxidant status in premature neonates. Clin. Sci. 84: 404-412

MORRE, S., CALDER, K. A. C., MILLER, N. J., RICE-EVANS, C. A. 1994: Antioxidant activity of saliva and periodontal disease. Free Rad. Res. 21: 417-425

PINZANI, P., PETRUZZI, E.., ORLANDO, C., GALlAI, R., SERIO, M., PAZZAGLI, M. 1998: Serum antioxidant capacity in healthy and diabetic subjects as determined by enhanced chemiluminescence. J. Biolumin. Chemilumin. 13: 321-325

RICE-EVANS, C., MILLER, N. J. 1994: The antioxidant status in plasma and body fluids. Methods Enzymol. 234: 279-293

WHITEHEAD, T. p. 1997: Enhanced chemiluminescent assay for measuring the total antioxidant capacity of serum saliva and cervicular fluid. Ann. Clin. Biochem. 34: 412-421

WHITEHEAD, T. P., THORPE, G. H. C., MAXWELL, S. R. J. 1992: Enhanced chemiluminescent assay for antioxidant capacity in biological fluids. Analytica Chim. Acta 265-277

TVEDTEN, H. 1999: Appendix II. In: WILLARD, M. D., TVEDTEN, H., TURNWALD, G. H.: Small animal clinical diagnosis by laboratory methods. W. B. Saunders Company, pp 370-372

YOUNG, I. S., TATE, S., LIGHBODY, J. H. McMASTER, D., TRIMBLE, E. R. 1995: The effects of desferrioxamine and ascorbate on oxidative stress in the streptozotocin diabetic rat. Free Rad. Biol. Med. 18: 833-840 